\title{
IMPLEMENTASINILAI-NILAIPENDIDIKAN DALAM SURAH ALI 'IMRAN PADA MTSN WATAMPONE
}

\author{
Implementation of Educational Values in Surah Ali 'Imran \\ at MTsN Watampone
}

\author{
M. Amir H.M. \\ Sekolah Tinggi Agama Islam Negeri Watampone \\ Jl. Hos Cokroaminoto Tlp./Faks. (0481)21395/23928 \\ Email: hm.amir.hm@gmail.com
}

\begin{abstract}
Abstrak
Penelitian ini bertujuan untuk menemukan wujud nilai-nilai pendidikan dalam surah Ali 'Imran dan impelementasinya pada Madrasah Tsanawiyah Negeri Watampone, yang secara ideal semua proses pendidikan pada madrasah tersebut berdasar pada Alquran, sebagai dasar normatif pendidikan Islam yang salah satu di dalamnya adalah surah Ali 'Imran. Untuk menemukan data yang akurat dipergunakan berberapa metode di antaranya, metode pendekatan pedagogis dan psikologis, sedangkan pengumpulan datanya dilakukan melalui library research da.n field research, dan diolah dengan metode kualitatif serta dianalisis dengan content analysis dan concept analysis.. Hasil penelitian ditemukan tujuan, fungsi dan metode pendidikan yang terdapat dalam surah Ali 'Imran. Lalu dikaitan dengan implementasinya pada Madrasah Tsanawiyah Negeri Watampaone. Para guru dan siswa yang ditunjuk sebagai sampel searah pendapatnya bahwa sesungguhnya nilai-nilai pendidikan dalam surah Ali 'Imran telah terimplementasi dengan baik pada madrasah tersebut, namun masih perlu penyempurnaan, terutama pada mata pelajaran tertentu yang bukan mata pelajaran pendidikan agama Islam (PAI).
\end{abstract}

Kata kunci: implementasi, nilai-nilai, pendidikan, surah Ali 'Imran

\begin{abstract}
This study aims to find educational values in Surah Ali Imran and its implementation in MadrasahTsanawiyahWatampone. In order to find accurate data, several methods were used, among others were the pedagogical and psychological approach. Data were also collected through library research and field research. Data processed using qualitative methods and analyzed with content and concept analysis. Result shows that surah Ali Imran contains educational values and schools goal, and methods of education have been in line with though still need further improvement, especially in non-Islamic education subjects
\end{abstract}

Keywords: implementation, values, educational, surah Ali 'Imran

\section{PENDAHULUAN}

$\bigcup^{\mathrm{m}}$ ecara filosofis, nilai sangat terkait dengan masalah etika. Itulah sebabnya etika sering disebut dengan filsafat nilai, yangmengkajinilainilai moral sebagai tolok ukur tindakan dan perilaku manusia dalam berbagai aspek kehidupannya. Sumber-sumber etika dan moral, selain dari agama juga boleh jadi bersumber dari pemikiran, adat istiadat atau tradisi serta ideologi. Dalam konteks nilai-nilai pendidikan dalam Islam, sumber etika atau nilai-nilai yang paling sahih adalah Alquran dan al-Hadis yang kemudian dikembangkan oleh hasil ijtihad para ulama atau cendekiawan muslim. Nilai-nilai yang bersumber dari pemikiran, adat istiadat atau tradisi serta ideologi sangat rentan dan kondisional, sebab kesemuanya merupakan produk budaya manusia yang kebenarannya bersifat relatif, lokal dan situasional. Sedangkan nilai-nilai Alquran, yaitu nilai-nilai yang bersumber dari Alquran bersifat mutlak dan universal (Said Agil Husain alMunawwar, 2005: 3). 
Karena itu, pendidikan Islam seyogianya menjadi pilihan pertama dan utama bagi masyarakat sebagai perwujudan untuk mencerdasakan mereka, baik kecerdasan intelektual, kecerdasan emosional, dan kecerdasan spiritual. Bahkan Menurut Omar Muhammad Al-Tomy Al-Syaibany seperti yang dikutip oleh Ramyulis bahwa pendidikan Islam tidak hanya bertujuan untuk menumbuhkan, mengembangkan dan membangun segala aspek kepribadian umat manusia dan segala potensi serta dayanya. Juga mengembangkan segala segi kehidupan dalam masyarakat, seperti sosial budaya, ekonomi, politik, termasuk memberi solusi atas segala permasalahan yang dihadapi umat manusia masa kini dan yang akan datang serta memelihara sejarah dan peradabannya(Ramayulis, 2011: 35).

Fungsi dan tujuan pendidikan tersebut akan dapat teraplikasi dalam kehidupan manusia apabila pendidikan diarahkan untuk menggali dan menyelami nilai-nilai pendidikan dalam Alquran. Karena Alquran diturunkan kepada Nabi Muhammad saw, untuk mengangkat derajat umat manusia dari lembah kegelapan, kezhaliman dan kebodohan, menuju alam yang terang benderang, berperadaban dan bermartabat. Sejarah menunjukkan bahwa masyarakat sebelum datangnya Islam atau yang sering disebut masyarakat jahiliah, yang tidak memiliki peradaban dan arah tujuan hidup, Nabi Muhammad saw dalam kurun waktu yang relatif singkat sekitar 23 tahun berhasil mengantar mereka ke dalam kehidupan baru yang berperadaban dan maju, yakni kehidupan yang disemangati dengan nilai-nilai pendidikan serta didasari dengan iman dan takwa kepada Allah swt.

Bagi umat Islam, Alquran merupakan asas dan landasan sekaligus inspirator seluruh kehidupan umat manusia, termasuk intelektualnya (M. Taufik, 2012: 45), yang oleh Fazlur Rahman dikatakan bahwa sumber definisi Islam, baik secara doktrinal maupun secara praksis, adalah Alquran dan Sunnah (Fazlur Rahman, 1987: 2-3). Karena itu, ketika berbicara tentang nilai-nilai pendidikan tidak bisa melepaskan diri dari petunjuk Alquran yang secara normatif tujuan yang ingin dicapai dalam proses aktualisasi nilai-nilai pendidikan dalam Alquran meliputi tiga dimensi atau aspek kehidupan yang harus dibina dan dikembangkan. Pertama, dimensi spiritual, yakni iman, takwa dan akhlakmulia. Kedua, dimensi budaya, yakni keperibadian yang mantap dan mandiri, tanggung jawab kemasyarakatan dan kebangsaan. Ketiga, dimensi kecerdasan yang membawa kepada kemajuan yang cerdas, kreatif, terampil, disiplin, etos kerja, profesional, inovatif dan produktif (al-Munawwar, 2005: 7-9).

Ketiga dimensi tersebut, mencerminkan tentang nilai-nilai pendidikan dalam Alquran yang tidak hanya berorientasi pada kepentingan kehidupan umat manusia di dunia tetapi juga untuk kepentingan kehidupan di akhirat. Bahkan pendidikan dalam Alquran tidak hanya berfungsi untuk mencerdaskan akal pikiran umat manusia yang lebih dikenal dengan kecerdasan itelektual, tetapi juga kecerdasan emosional, dan sipiritual,

Terkait dengan hal tersebut, Ali Abd. alA'azhim mengemukakan bahwa Alquran merupakan kitab yang sangat komprehensif yang di dalamnya tercakup persoalan filsafat, penalaran ilmiah, dan problema sosial yang mensinkronkan antara urusan dunia dan akhirat, antara ritus dengan perbuatan nyata, serta mengkombinasikan antara realisme dan idealisme. Islam memberi kesempatan kepada penganutnya untuk hidup dan berkarya di bumi, namun tetap memperhatikan serta memikirkan tentang apa yang ada di langit (Ali Abd. al-Azhim, 1989:75-76). Karena itu, untuk menemukan maknamakna yang tercakup dalam Alquran termasuk nilai-nilai pendidikan diperlukan keseriusan dan ketelatenan serta didasari dengan keyakinan bahwa Alquran bukan kitab ilmiah yang tersusun berdasarkan standar kitab/buku ilmiah yang disusun oleh manusia, tetapi Alquran mengandung makna ilmiah yang mendalam.

Demikian pentingnya pendidikan menurut Alquran, maka ayat pertama yang diturunkan oleh Allah swt kepada Nabi Muhammad saw adalah surat al-Alaq (96: ayat 1-5) memuat beberapa nilai pendidikan yang seharusnya diterjemahkan oleh umat Islam dalam kehidupan kesehariannya. Pertama, perintah membaca sebagai bagian dari proses pendidikan tergambar pada ayat pertama suarah al-Alaq tersebut. Kedua, hubungan antara sesama manusia dalam arti bahwa sebuah pendidikan, akan berjalan dengan baik apabila ada interaksi antara subjek dan objek pendidikan. Hal ini tergambar pada ayat kedua surah al-Alaq tersebut. Ketiga, bahwa pendidikan akan berhasil apa bila mereka yang terlibat dalam proses sebuah pendidikan berusaha menjaga hubungan baik dengan Allah saw baik melalui ibadah mahdah, maupun doa, karena dengan berkat kemurahanNya, manusia memperoleh ilmu pengetahuan. Hal ini tergambar ayat ketiga surah al-Alaq tersebut. Keempat, bahwa salah satu hasil dari pendidikan, terutama pendidikan formal adalah kemampuan 
peserta didik menulis, baik tulisan itu untuk kepentingan pribadinya, maupun orang lain. Hal ini tergambar pada ayat 4 surah al-Alaq tersebut. Kelima, bahwa manusia dituntut agar senantiasa menambah wawasan serta ilmu pengetahuannya, melalui penelitian dan pengkajian untuk menemukan ilmu pengetahunan yang belum diketahui sebagaimana janji Allah swt pada ayat keliam suarah Al-Alaq tersebut.

Kalau ayat-ayat yang pertama diturunkan oleh Allah swt, yakni surah al-Alaq ayat 1-5 mengandung berbagai unsur pendidikan, maka tentu surah yang lainpun demikian adanya termasuk surah Ali Imran, hanya saja keterbatasan kemampuan umat manusia menemukannya. Bahkan, Sepanjang penelusuran peneliti tidak menemukan hasil penelitian yang secara utuh mengungkap nilainilai pendidikan dalam surah Ali 'Imran, namun ditemukan beberapa referensi yang mendukung penelitian ini seperti kitab tafsir dan beberapa buku pendidikan. Karena itu, penelitian ini dengan segala keterbatasannya bertujuan mengungkap beberapa nilai-nilai pendidikan yang terdapat dalam surah Ali Imran, lalu melihat impelementasinya pada madrasah tsanawiyah negeri Watampone.

\section{Metode Penelitian}

Penelitian ini berlokasi pada Madrasah Tsanawiyah Negeri Watampone yang merupakan jenis penelitian diskriptif analitik dengan menggunakan pendekatan pedagogis dan psikologis. Kemudian datanya selain diperoleh melalui library research yakni buku-buku kepustakaan baik yang bersifat primer seperti kitab-kitab tafsir dan buku-buku pendidikan maupun yang bersifat skunder seperti kamus. Juga diperoleh melalui field research yakni data yang diperoleh dari lapangan melalui obsevasi wawancara yakni percakapan yang diarahkan pada suatu masalah tertentu antara interviewer (pengejar informasi) dengan interviewee (pemberi informasi). (Kartini Kartono, 1986: 171). Karena banyaknya jumlah guru dan siswa, maka untuk mendapatkan data yang valid digunakan sampel dengan teknik pengunaan proposional random sampling. Kemudian semua data yang diperoleh diolah dengan mengunakan metode kualitatif dan dianalisis melalui analisis isi (contnt analysis) dipakai untuk menganalisis makna yang terkandung dalam Alquran yang berkaitan dengan pendidikan serta analisis konsep (concept analysis), yakni menganalisis kata-kata kunci atau pokok yang mewakili sebuah gagasan atau konsep.

\section{PEMBAHASAN}

\section{Sekilas Tentang Surah Ali 'Imran}

Surah Ali 'Imran, dinamakan demikian karena di dalamnya ditemukan kisah keluarga 'Imran yakni Isa, Yahya dan Maryam dan ibu beliau. Sedangkan 'Imran adalah ayah Maryam as. atau kakek Nabi Isa. Surah ini terdiri dari 200 ayat, sekitar 80 ayat pertama berkaitan dengan kedatangan serombongan pendeta Kristen dari Najran (sebuah lembah di perbatasan Yaman dan Saudi Arabiyah) di masjid Madinah pada tahun sembilan hijriyah untuk berdiskusi dengan Nabi Muhammad saw. tentang Nabi Isa as. berkaitan dengan keesaan Allah swt. Diskusi dimaksud berjalan beberapa hari, namun tidak memperoleh kesepakatan.

Tujuan utama surah Ali 'Imran (keluarga 'Imran) ini adalah sebagai pembuktian tentang tauhid, keesaan dan kekuasaan Allah swt serta penegasan bahwa dunia, kekuasaan, harta dan ankanak yang terlepas dari nilai-nilai ilahiyah, tidak akan bermanfaat di akhirat kelak. Demikian pula hukum-hukum alam yang melahirkan kebiasaankebiasaan, pada hakikatnya diatur oleh Allah swt Yang Maha Hidup dan Qayyum (Maha menguasai), sebagaimana peristiwa-peristiwa yang dialami oleh keluarga Ali 'Imran. Melalui merekalah Allah swt menunjukkan keesaan, kekuasaan dan penguasaanNya terhadap seluruh alam. Serta membuktikan pula bagaimana suatu keluarga yakni ayah, ibu, anak suami dan istri, kesemuanya tunduk, patuh dan percaya kepada Allah Yang Maha Esa.

Penempatan urutan surah ini sungguh amat tepat, kerena sur ah al- Fatihah yang merupakan surah pertama merangkul seluruh ajaran Islam secara singkat. Sedangkan al-Baqarah yang merupakan surah kedua dari segi urutan, menjelaskan lebih rinci tentang ajaran-ajaran agama. Sementara surah Ali 'Imran yang merupakan urutan ketiga menekankan sesuatu yang menjadi dasar dan sendi utama tuntunan tersebut, yakni Tauhid. Tanpa tauhid, maka seluruh amalan yang dilakukan oleh umat manusia tidak akan bernilai di sisi Allah swt (Shihab, 2005: 3-4).

Nilai-nilai pendidikan yang dimaksud dalam surah Ali 'Imran antara lain:

\section{Tujuan pendidikan}

Tujuan pendidikan yang terdapat dalam surah Ali Tmran tidak terlepas dari pembentukan manusia seutuhnya yakni sehat jasmani dan rohani, memahami tugasnya sebagai hamba dari Allah swt dan memahami fungsinya sebagai makhluk sosial, 
serta memahami peranannya sebagai makhluk yang harus menjaga kelestarian lingkungan hidup. Karena itu dalam surah Ali Imran ditemukan beberapa tujuan pendidikan, yakni:

\section{Peningkatan ketauhidan kepada Allah swt}

Tauhid adalah berasal dari bahasa Arab

IX-I^J J (wahhada, yuwahhidu, tauhidan) yang berati mengesakan, mengimani bahwa tiada Tuhan selain Allah dan menyatukan. Kemudian dalam bentuk Ism al-Masdar-nya (tauhidan) berarti keyakinan atas keesaan Allah (Munawwir, 1984: 1646-1647). Karena itu, pendidikan hendaknya diarahkan peserta didik memahami dan meyakini kemahaesaan Allah yang terus menerus mengurus makhluk-Nya (QS. Ali Imran/3: 2).

Term $\left.{ }^{4}-1\right)$ pada ayat tersebut berakar kata dari huruf hamzah, lam $d m$ ha berarti sembahan. Kalau dikaitkan dengan Allah menunjukkan bahwa Dialah yang berhak disembah, (Abiy al-Husain Ahmad bin Faris bin zakariya.jilid I, 1999: 127), Term yH»J1 berarti memiliki sifat hidup, (Shihab, Volume 2, 2005: 5) Bila dikaitkan dengan Allah, -diartikan dengan Maha Hidup. Term f J-J-sJ berasal dari kata f $>2$ (qawama) berakar kata dari huruf qaf, wau dan mim yang mengandung pengertian terlaksananya sesuatu dengan kesempurnaannya. Allah dinamakan Qayyum karena Dia yang mengatur segala sesuatu yang merupakan kebutuhan makhluk, sehingga terlaksana secara sempurna dan berkesinambungan (M. Quraish Shihab, Volume 2, 2005: 6).

Dengan demikian, ayat tersebut memberi pemahaman bahwa Allah adalah Yang Maha Esa, tidak ada Tuhan selain Dia, Yang Maha Hidup tidak berawal dan tidak berakhir (mati), Yang Maha Kuasa, kekuasaan-Nya meliputi segala yang ada. Karena itu, Dialah yang berhak disembah dimintai pertolongan segala kebutuhan. Keyakinan seperti ini harus menjadi tujuan utama dalam proses pendidikan, sehingga nantinya setiap anak didik memiliki bekal untuk tidak bersifat angkuh dan takabbur karena prestasi dan prestise yang dimilikinya kelak setelah memperoleh ilmu pengetahuan.

\section{Peningkatan keyakinan terhadap kebenaran agama Islam}

Ajaran Islam meyakinkan kepada pemeluknya bahwa adalah suatu kealfaan ketika seseorang yang mencari agama selain Islam, karena sesungguhnya agama di sisi Allah adalah Islam (QS. Ali-Imran/3: 19).

Term (u> pada ayat tersebut memiliki beberapa pengertian, antara lain; ketundukkan, ketaatan, perhitungan, balasan, dan agama. Sedangkan term (^^-"-1-f) menurut asy-Syarawi seperti yang dikutip oleh M. Quraish Shihab, bahwa pengertian Islam tidak terbatas hanya risalah yang dibawah oleh Muhammad saw Tetapi Islam adalah ketundukan makhluk kepada Tuhan Yang Maha Esa dalam ajaran yang dibawa oleh para rasul. Hanya saja kata Islam untuk ajaran para nabi sebelum Muhammad saw, merupakan sifat, sedangkan umat Nabi Muhammad saw. memiliki keistimewaan dari segi kesinambungan sifat bagi agama umat Muhammad sekaligus menjadi tanda dan nama baginya (Shihab, volume 2, 2005: 40-41).

Menurut Ibnu Kastir bahwa yang dimaksud potongan ayat ${ }^{\wedge} \wedge \mathrm{L}^{\wedge} \mathrm{V}$ 4-151 J J -c. $<$ JJ A J I jl (tidak ada agama yang diterima di sisi Allah kecuali agama Islam), yaitu tidak ada agama di sisi-Nya yang diterima kecuali agama Islam yang merupakan agama oleh para rasul yang diutus oleh Allah swt sampai ajaran mereka ditutup dengan kedatangan Muhammad saw. Dengan kehadiran beliau semua ajaran atau syariat yang berbeda dengan syariat $\mathrm{Nabi}$ Muhammad saw tidak akan diterima di sisi Allah swt (Abiy al-Fidai Isma'il ibn Katsir al-Qurasyiy slDimisyqiy, t.th.: 354).

Dari keterangan di atas dipahami bahwa semua agama yang dibawa oleh para rasul pada dasarnya adalah Islam dalam arti mengandung makna keselamatan, penyerahan diri dan ketundukkan kepada yang menciptakannya, karena semua agama mengandung ajaran tauhid. Tetapi makna Islam pada ajaran mereka hanya sebatas sifat, bukan nama sebagai agama. Apalagi kalau ditelusuri ayat-ayat dalam Alquran tidak ada yang ditemukan kata Islam yang menunjuk kepada suatu agama kecuali yang menyangkut tentang kesempurnaan ajaran Muhammad saw. Karena itu, Allah tidak menerima agama kecuali agama Islam yang dibawa dan diajarkan oleh Nabi Muhammad saw (QS.Ali Imran/3: 85).

Dari ayat di atas dipahami bahwa siapa pun yang mencari agama setelah kehadiran Nabi Muhammad saw, selain agama yang diajarkan oleh beliau yakni Islam, tidak akan diterima oleh Allah swt Karena itu, makna al-Islam pada kedua ayat di atas, sebagai nama sebuah agama adalah agama yang dibawa oleh Nabi Muhammad saw dan berlaku sepanjang zaman. Walaupun diyakini bahwa semua agama yang datang sebelum Nabi Muhammad saw. juga dari segi pemaknaan mengandung makna Islam dan berimplikasi kepada ajaran tauhid, tetapi kebenarannya berlaku hanya sebatas setiap kurun 
waktu masing-masing para rasulnya.

Karena itu, salah satu tujuan pendidikan Islam, adalah terwujudnya manusia-manusia yang memperjuangkan keselamatan, ketaatan dan tunduk kepada khaliknya, yang dilandasi dengan keyakinan tentang kebenaran ajaran agama yang dibawa oleh Muhammas saw yakni agama Islam, yang menangkal seluruh kebenaran agama yang datang sebelumnya.

\section{Fungsi Pendidikan Islam}

Fungsi pendidikan Islam yang dimaksudkan adalah terbentuknya peserta didik melalui bimbingan dan arahan, sehingga mereka memiliki kecerdasan intelektual, kecerdasan emosional, dan kecerdasan spiritual dalam menata kehidupannya berdasarkan dengan petunjuk agama. Dalam surah Ali Imran terdapat beberapa ayat yang berkaitan dengan fungsi pendididkan Islam, antara lain:

\section{Meningkatkan pengetahuan}

Bahwa mereka yang dapat memahami secara mendalam tentang makna-makna yang terdapat dalam Alquran terutama ayat-ayat yang memerlukan penakwilan adalah mereka yang mendalam ilmu pengetahuannya (QS. Ali 'Imran/3: 7 ).

Term $\mathbf{U J} \wedge{ }^{\prime \prime \prime}>\mathrm{H}$ pada ayat tersebut adalah bentuk plural dari kata tunggalnya berasal dari fi'il al-madi $\mathrm{j}^{\wedge}{ }^{\wedge} \mathrm{j}$ berakar kata dari huruf ra, sin dan kha berarti tetap (Abiy al-Husain Ahmad bin Faris bin zakariya, jilid II, 1999: 395), juga berarti kokoh pada tempatnya, menguatkan, berurat berakar (Abidin Bisri dan Munawwir A. Fatah, 1999: 248). M. Quraish Shihab mengartikannya dengan sesuatu yang berat ditempatkan pada suatu tempat yang lunak. Seperti besi yang berat ditempatkan pada suatu tempat yang lunak (lembek), pasti besi itu masuk ke dalam sehingga tidak mudah goyah. Bahkan boleh jadi besi tersebut tidak tampak di permukaan, kemudian di artikan dengan mendalam. Bagi mereka yang mendalam ilmunya semakin mantap dan kokoh keimanan dan ketakwaannya kepada Allah. Lebih lanjut beliau mengemukakan bahwa ada sifat yang harus disandang oleh mereka yang mendalam ilmunya, yaitu; 1) takwa antara dirinya dengan Allah, 2) kerendahan hati antara dirinya dengan manusia, 3) zuhud yakni meninggalkan kenikmatan duniawi pada hal ia mampu memilikinya, karena ingin mendekatkan diri kepada Allah, dan 4) mujahadah, kesungguhan mengolah dirinya menghadapi nafsunya (M. Quraish Shihab volume 2, 2005: 16-17).
Dari keempat sifat tersebut menunjukkan bahwa orang yang mendalam ilmunya berarti pada dasarnya mereka telah memiliki keempat kecerdasan seperti yang telah disebutkan terdahulu dan sekaligus mewujudkan fungsi pendidikan yang harus terwujud dalam sebuah proses pendidikan.

Dengan demkian, untuk memiliki ilmu pengetahuan yang mendalam seperti yang dimaksudkan pada potongan ayat $\wedge \mathbf{j} \mathbf{j} \wedge \mathbf{i} \mathbf{J j 1 1 j}$

?•1»H memerlukan proses dan sistem yang tidak mudah, dan disinilah pendidik harus berfungsi maksimal memberi bimbingan dan arahan kepada peserta didik dan pada gilirannya mereka menyandang predikat tersebut, sehingga mereka memiliki wewenang dan kemampuan memahami ayat-ayat Allah, terutama ayat-ayat mutasyabih yakni ayat yang memiliki pengertian bersayap. Atau jika salah satu dari dua perkara mirip dengan yang lainnya sehingga tidak mampu dibedakan. (Muhammad Ali al-Hasan, 2007: 165). Bagi mereka memiliki pengetahuan yang kokoh dan mendalam tentu mereka peroleh melalui proses pendidikan, baik pendidikan formal, informal dan non formal serta hidayah atau petunjuk dari Allah swt.

\section{Peduli terhadap sesama umat manusia}

Salau satu tugas manusia sebagai khalifah Allah di atas persada bumi, adalah menjaga kemaslahatan antara sesama umat manusia, antara lain dengan berwasiat kepada kebaikan dan mencegah kemungkaran (QS. Ali 'Imran/3:110).

Term yang terdapat pada ayat tersebut berasal dari fi'il al-madi jl£ berakar kata dari huruf kaf, harf al-Illah (al-wawu) dan nun yang berarti berita tentang kejadian sesuatu (Abiy al-Husain Ahmad bin Faris bin zakariya, jilid VI, 1999: 148). Karena itu, yang dimaksud kuntum pada ayat di atas adalah kamu dijadikan atau diciptakan (Ahmad Mushthafa al-Maragiy, Juz 4, 1946: 28). Sedangkan yang dimaksud dengan ^^->i digunakan untuk semua kelompok yang dihimpun oleh sesuatu, seperti agama yang sama, waktu dan tempat yang sama, baik penghimpunannya secara terpaksa, maupun atas kehendak sendiri (Shihab, volume 2, 2005: 185) yang dimaksud umat pada ayat di atas adalah umat Islam.

Term UJJ-* ^ adalah fi'il al-mudari dari fi'il al-madi amara yanmg berakar kata dari huruf hamzah, mim dan ra berarti perintah tentang suatu persoalan, atau lawan dari larangan (Abiy al-Husain Ahmad bin Faris bin Zakariya, jilid I, 1999: 137), 
juga berarti memerintahkan. (Shihab, volume 2, 2005: 174). Term (-»JJ-»-AJI berarti sesuatu yang baik menurut pandangan umum suatu masyarakat selama sejalan dengan al-khair yakni nilai universal yang diajarkan oleh Alquran dan Sunnah. Sedangkan $>£$-j-«Jl adalah sesuatu yang dinilai buruk oleh suatu masyarakat serta bertentangan dengan nilai-nilai Ilahi (Shihab, volume 2, $2005: 175$ ).

$$
\text { Dengan demikian, ayat tersebut }
$$
menggambarkan bahwa salah satu ciri umat (Islam) yang terbaik adalah mereka yang senantiasa memerintahkan kebaikan $(<-* j j-\ll-\wedge l)$ dan mencegah kemungkaran $\left(\mathrm{j} \wedge{ }^{\prime} \ll^{\wedge}\right)$ - Mereka yang dapat melakukannya adalah yang beriman dengan benar. Ciri keberimanan mereka tampak di wajahnya dan dibuktikan dengan kreativitasnya yang selalu mengarah kepada kebaikan, dan menghindarkan dirinya dari perbuatan jelek yang bertentangan dengan ajaran agama. Padahal umat sebelum datangnya umat Islam, mereka hanya melakukan kejelekan, permusuhan di antara mereka dan tidak mengindahkan perintah amar ma'ruf dan nahi mungkar (Ahmad Mushthafa al-Maragiy, Juz IV: 1946:29)

Karena itu, kepedulian sosial pada diri suatu umat menjadi penting, seperti memberi bantuan baik material, maupun spiritual. Keinginan untuk saling membantu antara satu sama lain harusnya tumbuh pada diri seseorang sejak umur usia dini, sehingga sikap itu melekat dan perwujudannya menjadi kebiasaan bagi mereka. Hal ini dapat terwujud, ketika pendididkan dapat berfunsi secara maksimal terhadap penbentukan kepribadian anak, karena salah satu fungsi pendidikan adalah merubah moralitas peserta didik dari yang tidak baik menjadi baik dan dari yang baik menjadi lebih baik.

\section{Peningkatan Pendekatan Spiritual}

Kebutuhan manusia terhadap aspek spiritual merupakan kebutuhan fitrah yang pemenuhannya berkaitan langsung dengan kesempurnaan masa pertumbuhan dan kedewasaan kepribadian seseorang (G. Lindsay C.S. Hall, and R.E Thompson 1976: 361 ). Aspek spiritual terdiri dari; berpegang teguh kepada ketakwaan, mencintai kebaikan, kebenaran, keadilan, keindahan, dan membenci keburukan, kebatilan dan kezaliman (Najit, 2005 : $35)$.

Keterangan di atas, menunjukkan bahwa yang dimaksud dengan spiritual adalah suatu keadaan jiwa yang terdapat dalam diri manusia yang menyadarkannya tentang hubungan dirinya dengan penciptanya (Tuhan), sehingga muncul dalam dirinya bahwa semua kebutuhannya sangat tergantung dengan kehendak dan redhah dari Allah swt sebagai pencipta, pengatur dan pemilik segala sesuatu (QS. Ali 'Imran/3: 189 ).

Allah swt mampu melaksanakan ancamanNya itu, karena milik Allah kerajaan langit dan bumi, Dia yang menciptakan, memiliki dan mengaturnya, serta mengetahui segala rincian yang terjadi pada keduanya (Shihab,volume 2, 2005: 305). Karena Allah adalah pemilik segala yang ada di langit dan di bumi, maka kepada-Nyalah akan kembali segala sesuatu (QS. Ali 1mran/3: 109).

Bahwa Allah swt adalah pemilik segala sesuatu, yang mengatur semua urusan mereka sesuai dengan sunnatullah yang sangat bijaksana, dan tidak berubah karena perubahan situasi dan kondisi (al-Maragiy, juz 4,1946: 27). Allah swt menjelaskan bahwa Dialah pemilik segala yang ada, maka Dia berhak penuh mengatur, mewujudkan dan meniadakannya. Kekuasaan Allah tidak ada yang dapat menandinginya, itulah sebabnya semua persualan sekecil apapun pada akhirnya kembali kepada-Nya, dan tidak ada yang tersembunyi bagiNya (QS. Ali Imran/3: 5).

Bahwa Allah swt mengatur makhluk-Nya, maka tentu saja tidak ada yang tersembunyi bagiNya, baik makhluk yang berada di bumi, maupun makhluk yang berada di langit dengan seluruh tingkatannya (Shihab, volume 2, 2005: 9). Kalau segala sesuatu tidak ada yang tersembunyi bagi Allah swt maka seharusnya umat manusia ketika meniatkan atau pun melakukan sesuatu, menyadari dengan sungguh-sungguh bahwa ia dilihat dan diawasi serta dinilai, bahkan dibalas oleh Allah swt

Salah satu upaya agar keyakinan seperti tersebut, melekat pada diri seseorang melalui dengan pendidikan. Katena itu, salah satu fungsi pendidikan adalah memberi kesadaran kepada peserta didik tentang perlunya berkomunikasi dengan Allah melalui dengan ibadah, sehingga pendekatan spiritual dalam pendidikan menjadi sesuatu yang sangat penting agar terwujud manusia yang sadar tentang keberadaannya untuk mengabdi dan beribadah kepada Allah swt.

\section{Metode Pendidikan dan pengajaran dalam Surah Ali Imran}

Metode berarti: 1) cara teratur yang digunakan untuk melaksanakan suatu pekerjaan agar tercapai sesuai dengan yang dikehendaki, 2) cara kerja yang 
bersistem untuk memudahkan pelaksanaan suatu kegiatan guna mancapai tujuan yang ditentukan. (Departemen Pendidikan Nasional, 2002: 740). Dalam bahasa Arab metode dikenal dengan istilah thariqah yang berarti langkah-langkah strategis dipersiapkan untuk melakukan sesuatu pekerjaan (Ramayulis, 2008: 2-3).

Dengan demikian, yang dimaksud dengan metode pendidikan dan pengajaran adalah suatu cara yang di tempuh oleh pendidik ketika terjadi proses belajar mengajar, sehingga tujuan pembelajaran tercapai sesuai dengan sasaran yang diinginkan. Dalam Alquran terkhusus surah Al-Imran ditemukan berbagai metode pendidikan yang seharusnya menjadi landasan normatif dalam proses pendidikan dan pengajaran.

\section{Metode Diskusi/Dialog, dan Tanya Jawab}

Dalam pengertian yang umum, diskusi ialah suatu proses yang melibatkan dua atau lebih individu yang berintegrasi cecara verbal dan saling berhadapan muka mengenai tujuan atau sasaran yang sudah tertentu melalui cara tukar menukar informasi (information sharing), mempertahankan pendapat (self maintenance), atau pemecahan masalah (problem sovling) (Ramayulis, 2008: 289). Karena itu, yang dimaksud metode dialog/diskusi adalah suatu metode yang dilakukan dengan bertukar pikiran antara guru dengan peserta didik atau antara sesama peserta didik, guna mengambil kesimpulan dari suatu masalah. Atau guru memberi kesempatan kepada para peserta didik untuk mengadakan pembicaraan ilmiah guna mengambil kesimpulan atau membuat alternatif-alter natif pemecahan terhadap beberapa masalah yang harus dipecahkan bersama.

Salah satu kandungan surah Ali Imran adalah masalah dialog/diskusi, seperti yang dialami oleh Zakariya dan Maryam ketika berdialog/diskusi dengan Allah swt tentang kemungkinannya memperoleh anak (QS. Ali Tmran/3:40-41 dan 47).

Ketiga ayat tersebut memberikan gambaran tentang contoh metode dialog/diskusi yang ditunjukkan oleh Allah swt untuk memberi pemahaman tentang sesuatu yang dimaksud kepada lawan berbicara, yakni Zakariya (ayat 40-41) dan Maryam (ayat 47), yang pada prinsipnya ketiga ayat tersebut membicarakan tentang kemungkinannya mereka memiliki anak, yang secara empirik tidak mungkin lagi mereka memilikinya. Zakariya dan istrinya sudah tua sedangkan Maryam tidak ada laki-laki yang pernah menyentuhnya. Dari hasil diskusi/dialog mereka itu, Allah memastikan kepada mereka bahwa tidak ada yang mustahil bagiNya kalau sekiranya Dia menghendakinya.

Dengan demikian, metode diskusi/dialog dan tanya jawab perlu diterapkan dalam pembelajaran sebagai upaya untuk merangsang peserta didik berflkir atau mengeluarkan pendapatnya sendiri mengenai persoalan-persoalan yang dihadapi dan memerlukan pemecahaannya. Karena itu, metode ini tidak hanya berorientasi pada percakapan dan debat, tetapi yang lebih penting adalah pemecahan masalah, seperti yang ditunjukkan oleh Allah swt pada ketiga ayat tersebut.

\section{Metode Pemberian Hukuman}

Kata hukuman berasal dari kata hukum yang dalam Kamus Besar Bahasa Indonesia diartikan dengan; 1) peraturan atau adat yang secara resmi dianggap mengikat, yang dikukuhkan penguasa atau pemerintah, 2) Undang-undang, peraturan untuk mengatur pergaulan hidup masyarakat, 3) patokan (kaedah, ketentuan) mengenai peristiwa (alam dan sebagainya) yang tertentu, 4) kegunaan atau pertimbangan yang ditetapkan oleh hakim (dalam pengadilan), vonis. Setelah mendapat akhiran an menjadilah hukuman yang berarti; 1) siksaan dan sebagainya, yang dikenakan kepada orang yang melanggar undang-undang dan sebagainya, 2) keputusan yang dijalankan oleh hakim, 3) hasil atau akibat menghukum (Departemen Pendidikan Nasional, 2002: 410-411).

Karena itu, pemberian hukuman kepada peserta didik dimaksudkan sebagai balasan terhadap perbuatan mereka, dan tidak ada alternati lain kecuali diberikan hukuman, agar mereka menyadari kesalahan yang mereka lakukan. Dalam pendidikan Islam metode pemberian hukuman atau mengancam memberikan hukumam kepada mereka yang melanggar adalah sesuatu tindakan yang dibenarkan selama dilakukan dengan motivasi mendidik bukan balas dendam dan sebagainya. Allah swt mengancam orang kikir yang tidak mau menginfatkan hartanya, lalu hartanya itu Allah menjadikan kalung, kemudian memasangkannya di lehernya di had kemudian (QS. Ali-Imran/3: 180).

Memberi ancaman hukuman kepada peserta didik yang melanggar merupakan salah satu metode yang seharusnya diterapkan. Bahkan bukan saja bersifat ancaman, tetapi betul-betul dilaksanakan ketika mereka melanggar, agar tindakan itu menjadi pelajaran, tidak hanya bagi yang bersangkutan, tetapi juga kepada peserta didik lain. 


\section{Metode Perumpamaan}

Metode perumpaman adalah sebuah metode dalam pendidikan dengan mengemukakan perbandingan-perbandingan atau perumpamaan sesuatu dengan suatu yang lain. Metode ini menarik perhatian peserta didik ketika dikemukakan perumpamaan yang mudah dicerna akal, yang sebelumnya boleh jadi dalam bentu abstrak, lalu diambil perumpamaan yang berbentuk konkret (nyata), sehingga mudah dipahami dan diterima oleh akal. Allah swt mengemukakan perumpamaan dengan mengambil contoh yang konkret dari halhal yang bersifat abstrak. Allah swt menjadikan perumpamaan orang yang membelanjakan hartanya hanya kepentingan dunia, seperti angin yang menimpa tanaman lalau merusaknya (QS. Ali 'Imran/3: 117).

Term J-J-» matsal yang terdapat pada ayat tersebut berakar kata dari huruf min, tsa dan lam yang berarti membandingkan sesuatu dengan sesuatu yang lain (Abiy al-Husain Ahmad bin Faris binzakariya,jilidIII, 1999:296). Penyebutan kalimat $\mathrm{L} \pm \mathrm{j} \mathrm{xJ} 1 \quad i \backslash \mathrm{j} \wedge$ \SIA ^ mengisyaratkan bahwa infak yang mereka lakukan itu, bertujuan semata-mata untuk kepentingan kehidupan dunia. Harta mereka benar-benar dimanfaatkan untuk memperoleh kelezatan hidup, memperoleh prestasi dan prestise di dunia, sehingga harta mereka tidak dimaanfatkan di jalan Allah. Perumpamaan mereka seperti angin yang sangat dingin yang menghancurkan sawah dan ladang suatu kaum (Ahmad Mushthafa al-Maraghy, Juz 4, 1946: 40). Karena itu, ayat tersebut dipahami bahwa Allah swt menjadikan perumpamaan orangorang yang membelanjakan hartanya, semata-mata untuk kepentingan dunia, tidak ada niat untuk kepentingan akhirat, karena memang mereka tidak meyakini tentang adanya balasan di akhirat. Perbuatan mereka diibaratkan angin yang sangat dingin sehingga merusak tanaman. Maksudnya harta yang mereka infaqkan itu sama sekali tidak berguna bagi mereka.

Dengan demikian, metode pendidikan perumpamaan sangat berguna untuk mempercepat daya tangkal dan daya ingat siswa tentang sesuatu terutama yang bersifat abstara (tidak dirasakan langsung panca indra) lalu kemudian diangkat perumpamaannya dengan hal-hal yang konkret (dapat dirasakan langsung panca indra).

\section{Metode Kisah}

Term kisah berasal dari bahasa arab qsahashun adalah ism al-masdar dari kata kerja qashsha yang berakar kata dari huruf qaf dan shad yang berarti mengikuti sesuatu, mengikuti secara berturut-turut, mengikuti jejaknya, juga dapat berarti memotong (Abiy al-Huain Ahmad bin Faris bin zakariyah, juz V, 1999: 11). Karena itu, yang dimaksud metode kisah adalah metode yang dilakukan oleh guru ketika memberikan pelajaran, merekajuga menyampaikan kisah-kisah yang berkaitan pembahasan meteri pelajarannya. Metode ini selain membuka wawasan siswa, juga mengurangi ketegangan, sehingga siswa semakin rileks mengikuti materi pelajaran, tanpa mengurangi tujuan pembelajaran yang ingin dicapai. Metode kisah merupakan salah satu metode pendidikan yang cukup penting diterapkan, karena pada umumna kisah menyentuh jiwa pendengarnya, terutama kalau yang menyampaikan itu didasari dengan keikhlasan dan penghayatan (alJamil, 1995:125). Kisah Maryam ketika dipersiapkan melahirkan Isa, cukup menarik untuk dijadikan salah satu metode pendidikan, sebagaimana yang digambarkan oleh Allah dalam (QS. Ali Tmran/3: 42- 47)

Dari beberapa ayat tersebut, menggambarkan tentang kisah Maryam yang mendapatkan informasi dari malaikat tentang kelebihannya, dan keharusannya tunduk menyembah dan taat kepada Allah. Demikian pula informasi dari malaikat tentang kesediaannya memiliki anak yang bernama Isa. Lalu Maryam heran mendengar informasi itu, karena secara akal dan kebiasaan tidak mungkin ia memilki anak, karena tidak pernah bersentuhan dengan seorang laki-laki. Lalu malaikat berkata terimalah kenyataan ini karena kalau Allah menghendaki sesuatu pasti terjadL

Kisah tersebut menarik disampaikan kepada siswa ketika mengajarkan materi pelajaran yang berkaitan masalah akidah terutama ketika membahas sifat-sifat Allah swt, sifat-sifat nabi dan rasul serta reproduksi manusia.

Penyampaian metode kisah dalam proses pendidikan sangat penting untuk dikembangkan dan diterapkan, karena pada umumnya kisahkisah itu menyentuh akal pikiran, hati dan jiwa manusia, sehingga kisah yang disamapaikan itu mempermudah pemahaman siswa terhadap meteri pelajaran yang diajarkan pada waktu itu, terutama kalau kisah itu ada relevansinya dengan materi pelajaran.

\section{Metode Keteladanan}

Dalam bahasa Arab, keteladanan diistilahkan dengan uswah atau qudwah yang menurut al- 
Asfahani berarti suatu keadaan ketika seorang manusia mengikuti manusia lain, apakah dalam kebaikan, kejelekan, kejahatan atau dalam kemurtadan (Al-Asfahani, t.th: 105). Keteladanan yang dimaksud dalam pendidikan Islam adalah sesuatu yang diikuti oleh peserta didik dari pendidik atau orang yang dituakan baik dari perktaan maupun perbuatan.

Keberhasilan pendidikan pada zaman Rasulullah saw adalah keteladanan yang ditunjukkan oleh Rasululah sebagai uswah. Rasulullah ternyata banyak memberikan keteladan dalam mendidik para sahabatnya (Armai Arief, 2002: 116). Zakariya adalah teladan yang baik ketika beliau selalu berdoa agar mendapatkan keturunan yang baik (QS. Ali 'Imran/3: 38).

Menurut al-Maragiy, $\wedge_{-}-i j_{-} * \quad$ (zurriyyatan) berarti anak, kata ini dipakai untuk bentuk mufrad dan jamak. Sedangkan $V^{\prime} j \wedge$ (thayyibatan) Hal-hal yang nyaman dipandang, baik dari segi perilakunya (al-Maragiy, Juz 3, 1946: 142), maupun akhlaknya. Menurut Ibn Katsir, yang dimaksud dengan * .' j $\wedge$ (zurriyyatan thayyibatan) adalah anak saleh. Ketika Nabi Zakariya mengetahui keindahan tingkah laku dan ilmu pengetahuan yang dimiliki Maryam tentang Allah swt maka beliau berharap semoga dikaruniai oleh Allah anak saleh seperti Maryam, cerdas serta memikat hati bagi yang melihatnya, sehingga mereka berharap agar dikaruniai anak yang cerdas seperti Maryam (al-Dimisyqiy, fuz 3, t.th: 360). Menurut M. Quraish Shihab yang dimaksud $\wedge$ (di sanalah), yakni di Mihrab tempat Maryam berada dan menjawab pertanyaan Nabi Zakariya tentang sumber rezki Maryam, maka muncul keinginan Zakariya memperoleh anak, yang sebelumnya selalu dipendam karena ia sadar bahwa dirinya dan istrinya sudah tua. Melihat apa yang terjadi pada diri Maryam dan mendengar serta menyadari ucapan Maryam bahwa Allah memberi rezki kepada siapa yang Dia kehendaki. Ketika itulah Zakariyah bermohon kepada Allah untuk mendapatkan anak saleh (Shihab, volume 2:2005: 84).

Sikap Nabi Zakariya tersebut, yakni memohon kepada Allah swt untuk mendapatkan anak yang saleh, berakhlak muliah, memikat hati orang yang melihatnya, merupakan suatu sikap yang perlu diteladani. Sebagai orang tua seharusnya selalu berdoa kepada Allah semoga mendapat anak yang saleh, atau semoga anak yang telah dilahirkan selalu mendapat hidayah dari Allah swt agar menjadi anak saleh, yang selalu beribadah kepada Allah swt serta berbakti kepada kedua orang tuanya.

Dengan demikian metode keteladanan dalam pendidikan menjadi penting sebagai upaya untuk mewujudkan tujuan pendidikan. Pendidik yang dapat memberi contoh yang baik, seperti bertutur kata, bertata krama, bersopan santun sampai kepada pelaksanaan syariat agama secara utuh sangat berpengaruh secara fisik dan psikologi para siswa.

\section{Implementasi Nilai-nilai Pendidikan dalam Surah Ali 'Imran pada Madrasah Tsanawiyah Watampone}

Untuk memperoleh data yang akurat tentang implementasi nilai-nilai pendidikan dalam surah Ali Tmran pada Madrasah Tsanawiyah Negeri Watampone, peneliti terlebih dahulu melakukan wawancara dengan para guru dan siswa madrasah tersebut yang diyakin dapat mewakili temantemannya dan dapat memberikan informasi yang akurat.

Dari segi tujuan pendidikan yang meliputi peningkatan ketauhidan dan keyakinan terhadap kebenaran agama pada umumnya interview (pemberi informasi) baik dari guru maupun siswa menyatakan bahwa sesungguhnya tujuan pendidikan yang dimaksudkan itu telah terlaksana dalam setiap proses belajar mengajar di madrasah ini, walaupun masih ada kekurangan, ketika mata pelajaran di luar mata pelajaran Pendidikan Agama Islam (PAI), misalnya matematika, bahasa Inggris, bahasa Indonesia, karena keasikannya menjelaskan materinya mereka lupa menyinggung hal-hal yang berkitan dengan kebesaran Allah dan kebenaran agama, namun pada umumnya guru membaca Basmalah sebelum memulai pelajaran. Sebagaimana yang dikemukakan oleh Sabbang, guru bahasa Inggeris bahwa setiap memlulai pertemuan selalu diawalibacaanbasamalah, hanyasajatidakselamanya mengajak seluruh siswanya membaca Basmalah. Walaupun disadari bahwa membaca Basmalah adalah bagian dari upaya mengimplementasikan nilai-nilai ketauhidan kepada Allah swt, Ada pun upaya peningkatan kesadaran tentang kebenaran agama, hampir semua pertemuan selalu tersentuh masalah agama dari berbagai sudut pandang, termasuk masalah kemahaesaan Allah swt karena selalu mengemukakan contoh-contoh kalimat bahasa Inggris yang ada kaitannya dengan makna agama, misalnya mereka disuruh membuat kalimat dari kata sembahyang dan Tuhan (wawancara, $1 / 10 / 2014)$. 
Lain halnya dengan informasi yang disampaikan oleh Aminuddin seorang guru matematika bahwa setiap mengajar selalu diawali dengan pemberian salam, tentu dijawab oleh siswa. Hanya saja ketika menyampaikan materi jarang sekali menyinggung masalah yang bersifat spiritual, selain karena keterbatasan waktu, juga memang materinya pada umumnya hanya meningkatkan kecerdasan intelektual. Namun disadari bahwa sesungguhnya pelajaran matematika inklusif di dalamnya nilai-nilai spiritual, misalnya ketika memahami makna angka 1 (satu) sampai angka 10 (sepuluh), akhirnya angka 1 (satu) kembali muncul, artinya bahwa semua yang terjadi di alam ini berproses dari yang satu (Yang Masa Esa) kemudian kembali kepada asalnya yakni yang satu. Pemahaman seperti ini tidak selamanya terungkap dalam semua pertemuan, karena boleh jadi suatu pertemuan ada hal-hal yang harus diselesaikan dalam bentukperhitungan (Wawancara, 3/10/2014).

Alamsyah, seorang guru bidang studi komputer, mengemukakan bahwa setiap masuk ruangan selalu di awali dengan salam', dijawab oleh siswa dengan baik, sehingga suasana di kelas terasa akrab, sehingga ketika memulai pelajaran tidak ada perasaan tegang, baik bagi saya sebagai guru, maupun di kalangan siswa. Sebelum pelajaran dimulai, semua siswa diwajibkan berdoa dan membaca basmalah sebagai pernyataan sikap bahwa ada yang Maha Kuasa yang diharapkan memberikan pertolongan dalam semua aktivitas manusia. terutama ketika membuka komputer atau laptop. Ketika memperkenalkan cara pengoprasikannya, selalu mengingatkan mereka tentang keutamaan ilmu pengetahuan, sehingga alat seperti ini dapat terwujud. Sekali pun demikian, di balik dari alat ini harus disadari ada kekuasaan Allah swt karena alat ini tidak ada gunanya kalau tidak di topan dengan kekuatan akal manusia, sejak pembikinannya sampai pengoprasionalannya. Kalau Allah swt tidak menghendaki bermanfaat, Allah swt memutus satu saja urat saraf manusia, tentu tidak ada lagi yang dapat mengoperasionalkannya (Wawancara, $1 / 10 / 2014)$.

Dapatlah dipahami bahwa sekalipun mereka bukan secara khusus membina mata pelajaran materi pendidikan agama Islam (PAI), tetapi mereka tetap berusaha memasukkan nilai-nilai spiritual dalam setiap menyampaikan meteri pelajarannya, walaupun dalam beberapa kesempatan terdapat masalah teknis yang tidak bisa dihindari. Namun demikian, pada dasarnya tujuan dan fungsi nilainilai pendidikan dalam surah Ali 'Imran telah terimplementasi dengan baik.

Dari segi metode pendidikan dan pengajaran yang tersirat dalam surah Ali 'Imran, seperti metode diskusi/dialog dan tanyak jawab, hukuman, perumpamaan, Kisah, dan keteladanan, menurut M. Taufik guru bidang studi Alquran Hadis mengemukakan bahwa pada dasarnya semua metode tersebut selalu diperktekkan ketika mengajar, tetapi tidak sekaligus, tergantung materi yang diajarkan, boleh jadi pertemuan pertama digunakan metode kisah dan perumpamaan, tetapi pertemuan berikutnya yang digunakan metode hukuman dan diskusi/dialog atau tanyak jawab, demikianlah terus menerus dalam setiap pertemuan pasti metode tersebut ada yang digunakan, karena disadari bahwa bagaimanapun bagusnya materi pelajaran kalau tidak ditopan dengan metode pengajaran yang baik, pada umunya tidak berhasil maksimal, bahkan menimbulkan kejenuhan para siswa, yang berakibat pada ketidak pahaman mereka terhadap materi yang diajarkan (Wawancara, 5/10/2014).

Keterangan di atas searah dengan padangan Martan Aziz, pengasuh mata pelajaran IPA bahwa tanpa metode pengajaran proses belajar mengajar tidak akan dapat berhasil dengan baik. Karena itu, metode pengajaran yang terdapat pada surah Ali 'Imran tersebut pada prinsipnya saya telah mengimplementasikannya dalam setiap pertemuan, sekalipun tidak sekaligus, tergantung dengan objek pembahasan, apalagi materi pelajaran IPA terkadang ada hal-hal yang spesifikasi tidak memerlukan metode, hanya diperlukan kecakapan dan keterampilan.

Selain apresiasi dari guru, siswa juga memberikan apresiasi (Anisa Riadatul Jannah kelasa V, Khaeratul Hisan kelas VII, dan Rilna Nisa Alifiyah, kelas IX), mereka memiliki pandangan yang sama, sesuai dengan pandangan dan pengalamannya selama mengikuti proses belajar mengajar di Madrasah Tsanawiyah Negeri Watampone, bahwa semua guru senantiasa memberikan spirit keagamaan terutama yang berkaitan dengan keyakinan, ibadah, dan akhlak ketika mereka mengajar, tidak terkeculai guru yang mengajar selain mata pelajaran Pendidikan Agama Islam (PAI). Demikian pula pada umumnya mereka menggunakan metode pengajaran seperti yang terdapat pada surah Ali 'Imran, sekali pun mereka bervariasi dalam penerapannya (wawancara, 10/10/2014). 
Dari hasil wawancara tersebut, dapat dipahami bahwa pada dasarnya metode pendidikan dan pengajaran yang terdapat dalam surah Ali 'Imran telah terimplemnetasi dengan baik pada Madrasah Tsanawiyah Negeri Watampone, walau pun masih terdapat kekurangan-kekurangan yang masih memerlukan kesadaran serta perhatian baik dari kalangan guru, maupun pimpinan dan segenap yang berkompeten terhadap pelaksanan proses belajar mengajara pada madrasah tersebut, sehingga semakin hari semakin terasa peranan Alquran khusus surah Ali 'Imran sebagai dasar normatif tujuan, fungsi dan metode pendidikan Islam.

\section{PENUTUP}

Surah Ali 'Imran merupakan surah ketiga dalam Alquran yang di dalamnya terdapat nilainilai pendidikan yang seharusnya dikembangkan terus dalam kehidupan umat manusia, terutama ketika dipahami tujuan utama surah tersebut yaitu pemahaman tentang ketuhidan, keesaan dan kekuasaan Allah swt serta penegasan ba,hwa dunia, harta dan anak-anak yang terlepas dari nilai-nilai ilahiyah tidak akan bermanfaat di akhirat kelak. Pemahaman dan keyakinan seperti ini harusnya terpatri pada diri seseorang sejak kecil melalui jalur pendidikan, baik pendidikan formal, informal maupun non formal.

Tujuan dan fungsi pendidikan dalam surah Ali 'Imran tidak terlepas dari semangat peningkatan ketauhidan, yakni keyakinan bahwa segala sesuatu akan kembali kepada penciptanya yang mengatur dan memeliharanya, serta keyakinan tentang kebenaran agama Islam yang dibawa oleh Rasululan saw. Sedangkan fungsi pendidikan yang terdapat dalam surah Ali Imran antara lain; peningaktan ilmu pengetahuan, peduli terhadap sesama umat manusia dan peningkatkan nilai-nilai spiritual dalam segala segi kehidupan. Ada pun metode pendidikan yang terdapat dalam surah Ali 'Imran antara lain adalah metode diskusi/dialog dan tanyak jawab, metode pemberiah hukuman, metode perumpamaan, metode kisah, dan metode keteladanan.

Tujuan, fungsi dan metode pendidikan dalam Alquran tersebut, pada dasarnya telah terimplementasi pada Madrasah Tsanawiyah Negeri Watampone, walapun masih terdapat beberapa guru yang belum melaksanakannya secara maksimal, karena mata pelajaran yang diajarkan itu tidak selamanya sesuai dengan metode-metode tersebut, tetapi setidaknya niali-nilai pendidikan yang terdapat dalam surah Ali 'Imran telah menjadi dasar normatif dalam pengembangan pendidikan di masa yang akan datang.

\section{Ucapan Terima Kasih}

Ucapan terima kasih disampaikan kepada pengelola Jurnal Al-Qalam atas kesediannya memuat tulisan ini. Ucapa yang sama disampaikan kepada bapak/ibu dan saudara selaku narasumber atas kesediaannya memberi informasi yang valid, sehingga penelitian ini dapat selesai sesuai dengan waktu yang direncenakan. Akhirnya ucapan terima kasih disampaiakan pula kepada civitas akademika STAIN Watampone atas motivasi dan bantuannya, demi terselesaikannya penelitian ini.

\section{DAFTAR PUSTAKA}

Ahmad bin Faris bin zakariya, Abiy al-Husain. 1999. Mu'jam Maqyis al-Lugah. Bairut: Dar al-Jili.

Arif, Armai. 2002. Pengantar Ilmu dan Metodologi Pendidikan Islam. Jakarta: Ciputat Pres.

al-Asfahani, Al-Ragib. t.th. Mufradat alfazh alQur'an. Damsyiqy: Dar Al-Qalam.

al-Abrasy, Mohammad Athiyah. 1969. Ruh alTarbiyyat wa al-Ta'lim. Qairo: Isa al-Baby alHalaby.

al-'Azhim Ali, Abd. 1989. Epistemologidan Aksiologi Ilmu, terj. Khalilullah Ahnas Masykur Hakim. Bandung: Rosda Karya.

Bisri, Abidin, dan Munawwir A. Fatah. 1999. Ramus Indonesia Arab, Arab-Indonesia. Surabaya: Pustaka Progressif.

C.S. Hall, G. Lindsay, and R.F. Thompson. 1976. Psyckology. New York: Worth Publishers, Inc. Departemen Pendidikan Nasional. 2002. Kamus Besar Bahasa Indonesia. Jakarta: Balai Pusataka.

al-Jamali, Moh. Fadhil. 2002. Falsafah Pendidikan Dalam al-Qur'an, terj. Junaidi al-Falasany. Sjurabaya: Bina Ilmu.

Kartone, Kartini. 1986. Pengantar Metodologi Research Sosial. Bandung: Penelitian Alumni. Munawwir, Ahmad Warson. 1984. Al-Munawwir Kamus Arab Indonesia. Yogyakarta: Pondok Pesanteren al-Muanawwir.

al-Maragiy, Ahmad Miishthafa. 1946. Tafsir alMaragiy. Mesir: Syakitaun wa Mathbaatun Musthafa al-Babiy al-Halabiy wa Auladuh.

al-Munawwar, Said Agil Husain. 2005. Aktualisasi 
Nilai-Nilai Al-Qur'an Dalam Sistim Publishing Company.

Pendidikan Islam. Ciputat: PT. Cipoutat Ramayulis. 2008. Metodologi Pendidikan Agama Press.

Islam. Jakarta: Kalam Mulia.

Najit, Muhammad Utsman. 2005. Ilmu Jiwa Dalam. 2011. Ilmu Pendidikan Islam. Jakarata: al-Qur'an. Jakarta: Pustaka Azzam. Kalam Muliah.

al-Qurasyiy sl-Dimisyqiy, Abiy al-Fidai Ismail ibn

Shihab, M. Quraish. 2005. Tafsir Al-Misbah Pesan, Katsir. t.th. Tafsir al-Qur'an al-Azhim, Juz I. Mesir: Dar al-Kutub.

Rahman, Fazlur. 1987. Health and Medicine in the Islam Tradition. New Yok: The Crossroad Kesan dan Keserasian al-Qur'an, volume 2. Jakarta: Lentera Hati.

Taufik, M. 2012. Kreativitas Jalan Baru Pendidikan Islam. Solo: Kurnia Kalam Semesta. 